\title{
Current Situation of Renewable Energy in Saudi Arabia: Opportunities and Challenges
}

\author{
Gaydaa Al Zohbi ${ }^{1} \&$ Fahad Gallab AlAmri² \\ ${ }^{1}$ Department of Mathematical and Natural Sciences, Prince Mohammad Bin Fahd University, Al Khobar, \\ Kingdom of Saudi Arabia \\ ${ }^{2}$ Department of Mechanical and Energy Engineering, College of Engineering, lmam Abdulrahman Bin Faisal \\ University, Dammam, Kingdom of Saudi Arabia \\ Correspondence: Gaydaa Al Zohbi, Prince Mohammad Bin Fahd University, P.O. Box 1664- Al Khobar \\ 31952-Kingdom of Saudi Arabia. Tel: 966-13-849-8502. E-mail: ghizoh_m@hotmail.com; \\ galzohbi@pmu.edu.sa
}

Received: November 17, 2019

Accepted: March 23, $2020 \quad$ Online Published: March 30, 2020

doi:10.5539/jsd.v13n2p98

URL: https://doi.org/10.5539/jsd.v13n2p98

\begin{abstract}
The Kingdom of Saudi Arabia set out the national Vision 2030 that aims to accelerate efforts toward attaining sustainable development goals. In the framework of this Vision, Renewable energy plan has been set up and aims to ensure renewable energy growth that presents a key priority for achieving sustainable development. The present paper highlights the current situation of pollution and renewable energy in the Kingdom and presents the policies and actions stipulated in the Kingdom's Vision 2030 to develop a renewable energy sector. In addition, the barriers facing the implementation of solar and wind energy in the Kingdom of Saudi Arabia has been carried out. Also, the different challenges facing the waste management has been presented. The paper concludes with some recommendations to develop the renewable energy sector in the Kingdom.
\end{abstract}

Keywords: Saudi Arabia, pollution, Renewable energy, fossil fuels, Vision 2030

\section{Background}

Saudi Arabia is located between the Red Sea and the Arabian Gulf and it presents the largest territory of the Arabian Peninsula. The country has a total population of 33,413,660 as of 2018 with an annual growth rate of $1.49 \%$ (2019), whereas, the immigrants represents around 37\% of the Saudi population (Özkazanç-Pan 2019). However, $80 \%$ of the Saudi population live in ten major urban centers-Riyad, Mecca, Medina, Hofuf, Ta'if, Khobar, Dammam, Yanbu, Dhahran and Jeddah. The Kingdom has a total area of 2.15 million $\mathrm{km}^{2}$ and it is dominated by desert, semi desert and shrub land. The topographic features are characterized by mountain ranges in the Western region, situated parallel to the coast of the Red Sea. However, the Coastal Regions include the coastal strip along the Red Sea with a width of 16 to $65 \mathrm{~km}$. The Central Hills run close to the western mountains and lie in the center of the country while the South Eastern region is almost covered by the Rub Al-Khali desert. The diverse topographical features of the Kingdom cause a change of climate from one region to another. The climate of the Kingdom is characterized by moderate in the West and Southwestern part, by dry and hot in summer and cold in winter in the interior while it is characterized by hot and humid in the coastal areas .

The Kingdom ranks the first proven oil reserves and the fourth largest proven gas reserves in the world. In addition, it is on the top list of oil producing and exporting countries in the world. Moreover, it is counted among the top five world's biggest oil-consuming country after USA, China, India and Japan. The country has a significant high electricity consumption per capita with an average of 193,472,186 MWh between December 2000 and December 2018 (mundi 2020). Despite the country has an abundant wind and solar energy resources, the use of these resources is negligible.

The Kingdom is characterized by rapid growth population, industrialization, urban development and robust economy. The country's economy is based on oil and is considered as one of the top twenty economies in the world where the Gross Domestic Product per capita (GDP) was recorded at 20775.20 US dollars in 2018.

The intense use and production of fossil fuel in KSA caused many environmental issues such as air and water pollution which have negative effects on human health and environment. Some renewable energy resources such 
as hydroelectric power, biomass and bio-wastes (bioenergy and biofuels), solar energy, wind energy, and geothermal energy are sustainably available in the Kingdom and therefore, suitable use of these resources could certainly cover a significant part of electricity's demand in sustainable and environment friendly way. In addition, the use of renewable energy and energy efficiency can reduce the environmental issues and its impacts on the human health, minimize the global warming emissions, limit fossil fuels depletion and decrease dependence on coal and other fossil fuels. A study has been done by Al Garni et al. showed that the most effective renewable energy technologies in the KSA are photovoltaic (PV), concentrated solar power (CSP), and wind energy, respectively (Al Garni, Kassem et al. 2016).

Saudi Arabia is engaging to attaining sustainable development, and the Kingdom's Vision 2030 conforms with the three pillars of sustainable development, economic, social, and environmental. Hence, in the comprehensive of the Vision's 2030, the government set out a plan to develop an energy security strategy that aims to diversify its energy sources and to build renewable energy power sector for KSA. According to Ramli et al, the implementation of renewable energy in the kingdom of Saudi Arabia will decrease the level of $\mathrm{CO}_{2}$ emissions, contribute to increase the revenues and create more jobs (Ramli, Hiendro et al. 2016).

A study has conducted by Tlili et al, to describe the current status of energy in KSA and it focused on renewable energy, major achievements, and current government policies and challenges (Tlili 2015). Another study has been carried out by (Mosly and Makki 2018) to depict the current status of renewable energy and the willingness to adopt its technologies in the western region of Saudi Arabia. Results indicated that education is fundamental in raising the awareness level of renewable energy technologies while the economic factor is the main factor influencing the willingness to adoption.

The present paper highlights the current status of pollution and energy consumption by different sectors and reviews the renewable energy resources available in the kingdom. In addition, it summarizes the new and current government policies and plans stipulated by the vision 2030 to develop renewable energy sector and outlines the major barriers faced the development of renewable energy resources in the country. The paper concludes with some suggestions and recommendations for the development of renewable energy sector in KSA.

\section{Status of Energy Consumption in KSA}

Figure 1 displays the energy consumption by sectors in Saudi Arabia between 1990 and 2017. It can be noticed that the transport and the industry sectors are by far the most energy-intensive in the country while the agriculture and the forestry sector is the lowest one. In 2017, Saudi Arabia consumed 140,709 ktoe of energy while it consumed 39, 487 ktoe in 1990.

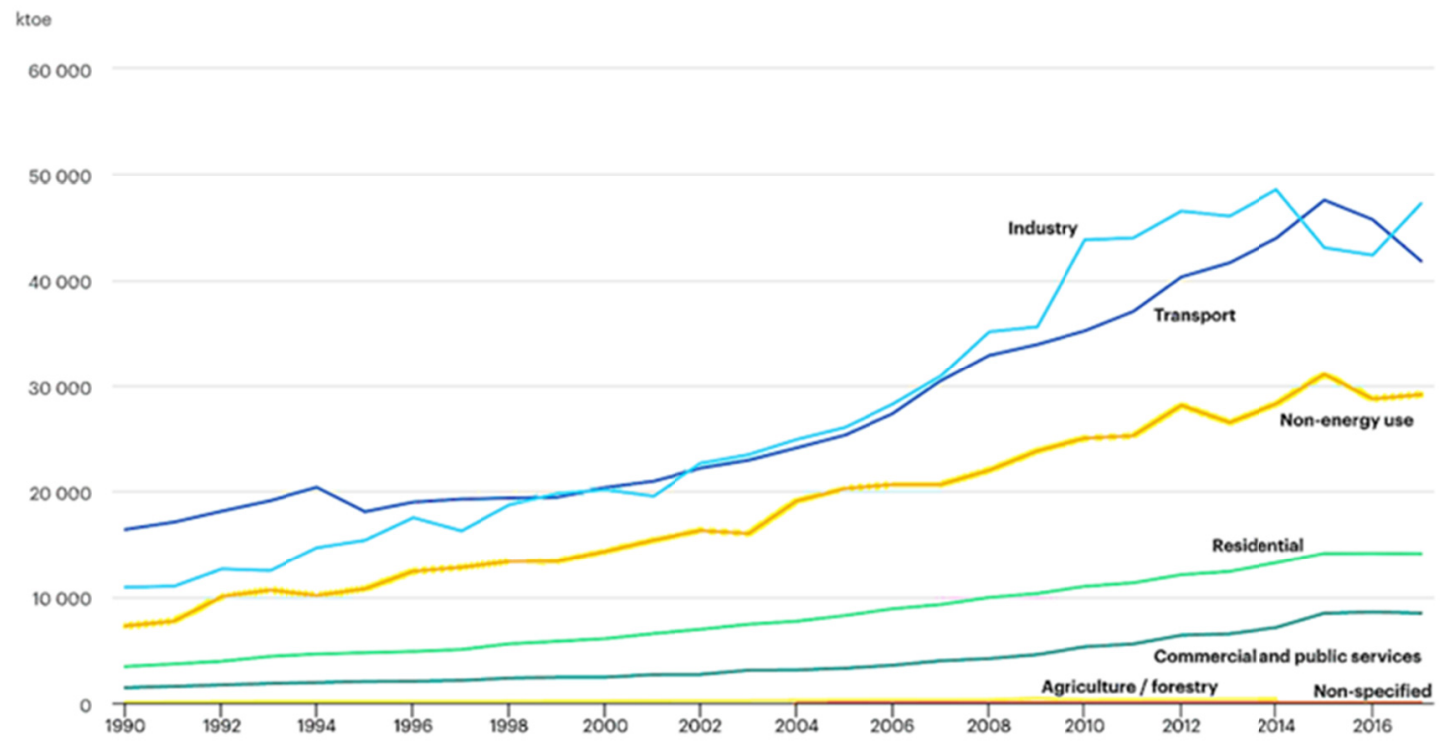

Figure 1. Energy consumption by different sectors between 1990-2017 (IEA 2019)

Figure 2 deals with the share of energy generation capacity by fuel type between 1990 and 2017. It can be observed that in 2017 , oil products contributed the most at 92,170 ktoe, followed by electricity at 23,670 ktoe, 
natural gas at 22,544 ktoe, crude oil at 2,318 ktoe and biofuels and waste at $7 \mathrm{ktoe}$.

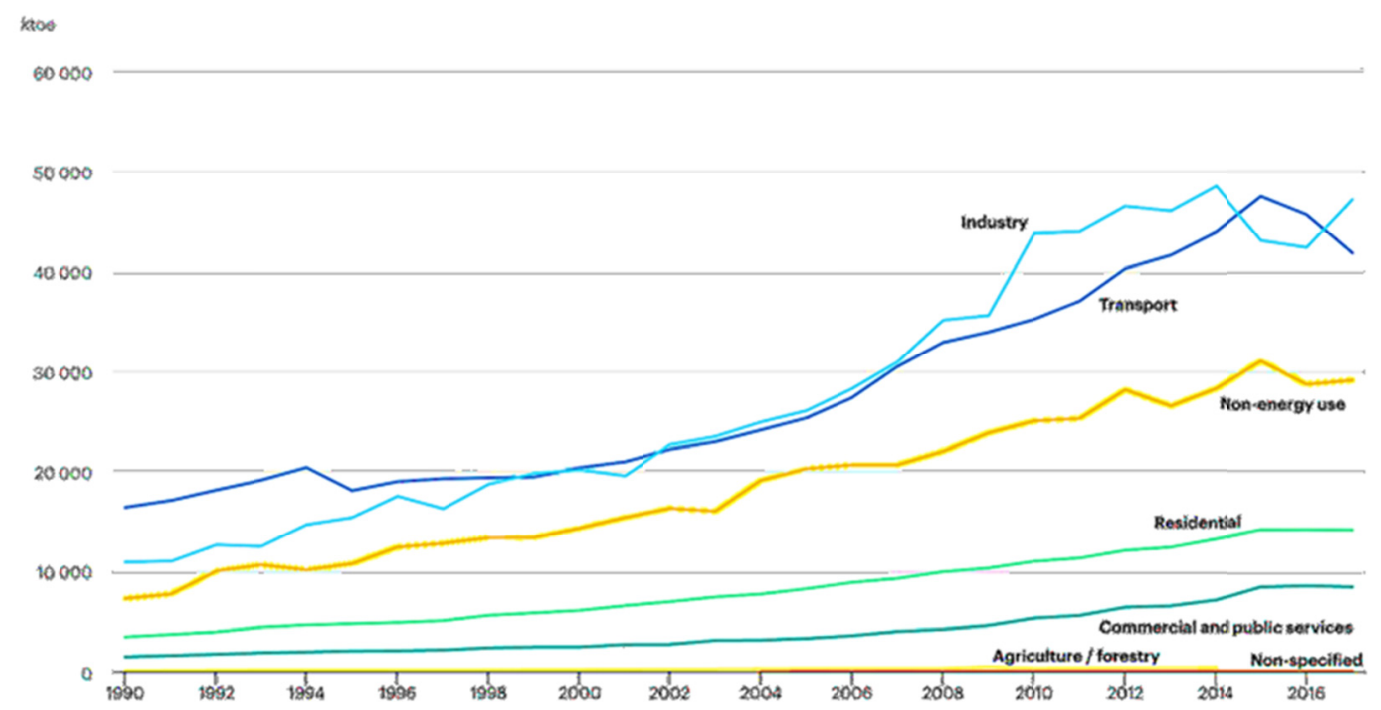

Figure 2. Share of electricity generation capacity (\%), by Fuel Type, Saudi Arabia (IEA 2019)

\subsection{Industrial Sector}

The energy consumption by industrial sector was 47194 ktoe in 2017, which is $33 \%$ of the total energy consumption. According to the data provided by the Electricity \& Cogeneration Regulatory Authority, the main energy usage in the industries are petrochemicals, steel, cement and water desalination (SEEC 2020). However, $25 \%$ of the domestic oil and gas production are used in desalination plants and the share is expected to increase to $50 \%$ by 2030 (Caldera, Bogdanov et al. 2018). A report by General Electric (GE) suggests that Saudi Arabia requires 300,000 barrels of oil per day for the desalination plants on the country's Eastern and Western coasts.

\subsection{Transport Sector}

The energy consumption by transport sector was 41790 ktoe in 2017 , which is $29 \%$ of the total energy consumption. This sector is suffering from an excessive consumption due to low fuel price and low efficiency of currently used vehicles. The fuel price in the Kingdom is the lowest in the world and the Saudi population prefers the vehicles with big engines, which increase fuel consumption, regardless efficiency and fuel consumption.

\subsection{Residential Sector}

The energy consumption by residential sector was 14091 ktoe in 2017, accounting for about $9.9 \%$ of the total energy consumption. According to the data provided by the Electricity \& Cogeneration Regulatory Authority, the main energy usages in the buildings are air conditioning which represents $50 \%$ of this consumption, lighting, equipment, and other devices. During the summer months, Saudi Arabia's electricity consumption increases as domestic demand for air conditioning rises.

\subsection{Non Energy Use Sector}

The energy consumption by non-energy use sector was 29145 ktoe in 2017 , accounting for about $20.6 \%$ of the total energy consumption. Non energy use encompasses energy products that is not consumed as a fuel or transformed into another fuel.

\subsection{Commercial and Public Service Sector}

The energy consumption by Commercial and public service sector was 8458 ktoe in 2017, accounting for about $6 \%$ of the total energy consumption. A study conducted by Saudi Electricity Company revealed that lighting consumption rate in some commercial buildings exceeds $30 \%$ of the total consumed energy for the optimal lighting usage.

\subsection{Agriculture and Forestry Sector}

The energy consumption by agriculture and forestry sector was 394 ktoe in 2017 , accounting for about $2.8 \%$ of 
the total energy consumption. The geographical and climatic constraints (droughts) are the leading reason of the low energy consumption by the agriculture sector. Saudi Arabia imports most of its agricultural and food product requirements.

\section{Pollution in Saudi Arabia}

Saudi Arabia has generated a number of environmental issues caused predominately by relying on fossil fuel for energy generation and transportation, urbanization, industrialization and rapid growth of population. The situation of air, water and soil pollution in the Kingdom of Saudi Arabia is presented here below.

\subsection{Air Pollution}

Air pollution is rapidly becoming a main environmental problem of public worry in quite a lot of developing countries of the world. It can affect public health and local/regional weather and climate. Ambient air pollution in major cities of Saudi Arabia is a substantial environmental and health concern. The nations with the highest and lowest air pollution in the world are presented in Figure 3. It can be noticed that the highest air pollution is registered in Saudi Arabia.

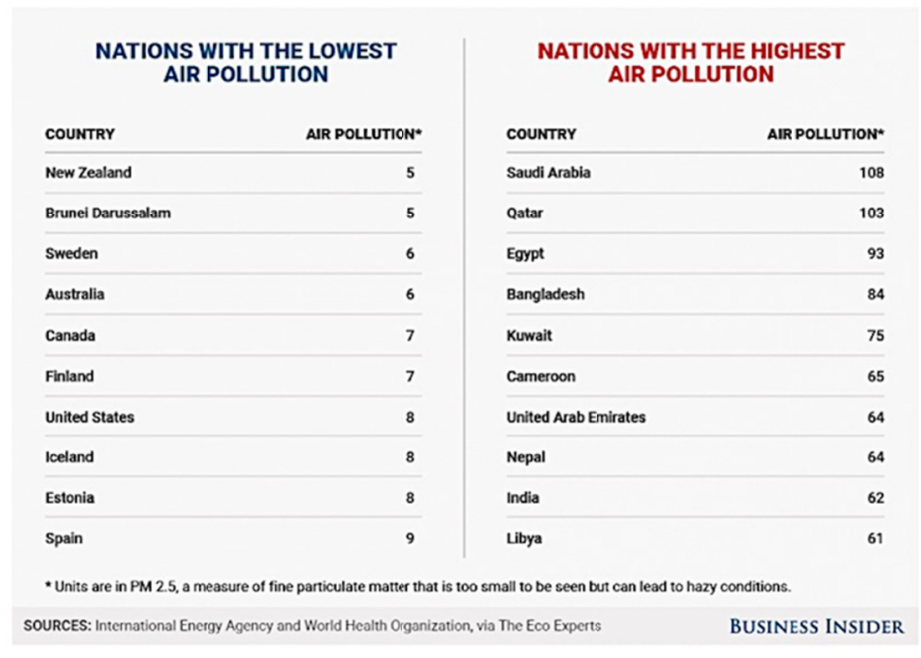

Figure 3. Nations with the highest air pollution

The kingdom of Saudi Arabia produces the largest amount of crude oil in the world. Hence, the production of this huge amount of crude oil and refining process create different kinds of greenhouse gases which cause air pollution. In addition, Saudi Arabia relies on the fossil fuels such as Fuel Oil (HFO), natural gas, diesel oil, and crude oil to produce energy, which generate an enormous emission of $\mathrm{CO}_{2}$. The domestic primary energy and power consumption in Saudi Arabia is rising at an alarming rate.

Figure 4 deals with the annual mean microgram per cubic meter of $\mathrm{PM}_{10}$ in cities worldwide in 2016. It can be noticed the highest levels of small and fine particulate pollution $\left(\mathrm{PM}_{10}\right.$ and $\left.\mathrm{PM}_{2.5}\right)$ were recorded in South-East Asia and the Mediterranean. Three cities, located in the Kingdom of Saudi Arabia (Riyadh, Al Jubail and Dammam) are among the twenty worst cities worldwide for air pollution. 


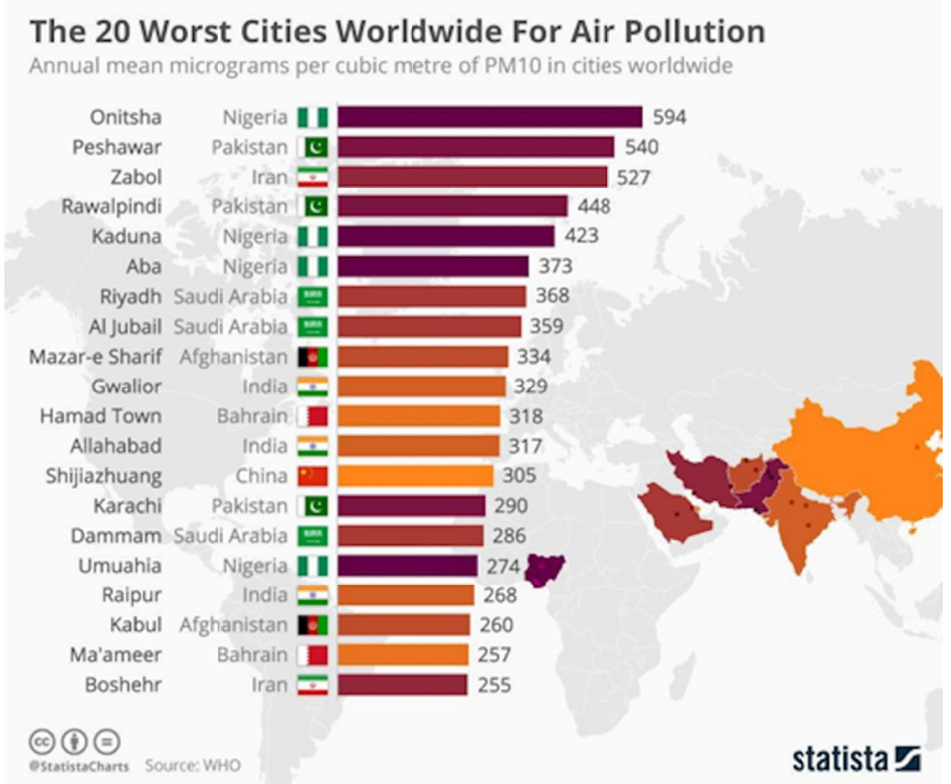

Figure 4. The 20 worst cities worldwide for air pollution in 2016 (McCarthy 2016)

The electricity consumption in the Kingdom of Saudi Arabia between 2006 and 2017 is presented in Figure 5. It can be observed that the electricity consumption increased significantly from $163,151,087 \mathrm{MWh}$ to $288,656,429$ MWh between 2006 and 2017 at an increasing annual rate that reached a maximum of $8.5 \%$ in 2012 and then decreased to $0.42 \%$ in 2017 .

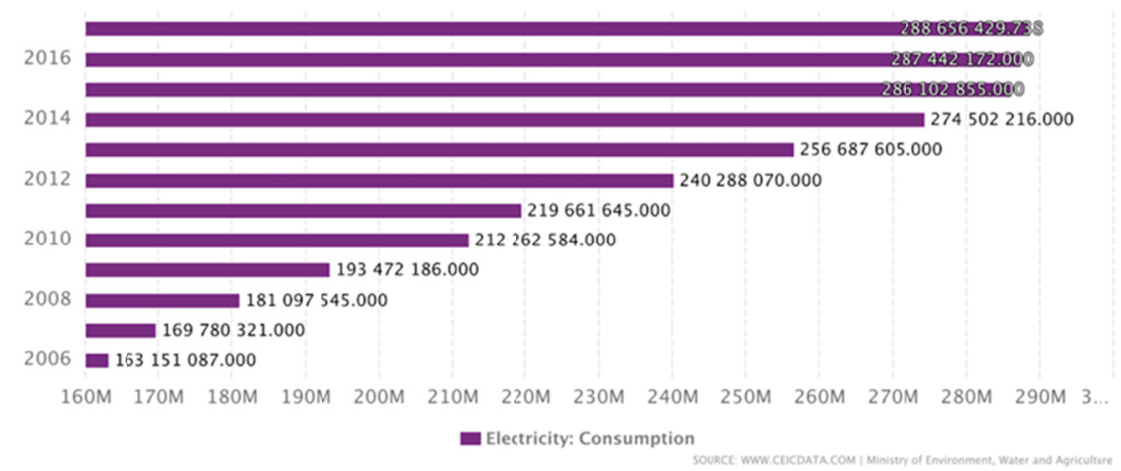

Figure 5. Electricity consumption in the KSA between 2006 and 2017 in MWh

The emissions of carbon dioxide, which is the primary greenhouse gas, are released into Earth's atmosphere by burning fossil fuels (coal, natural gas, and oil), solid waste, and as a result of certain chemical reactions (e.g., manufacture of cement). The $\mathrm{CO}_{2}$ emissions in the Kingdom of Saudi Arabia between 1970 and 2016 is presented in Figure 6. It can be observed that the $\mathrm{CO}_{2}$ emissions of Saudi Arabia raised from 231,759.6 kt to $517,079.4 \mathrm{kt}$ between 1997 and 2016, at an increasing annual rate that reached a maximum of $7.55 \%$ in 2010 and then decreased to $0.92 \%$ in 2016 . 


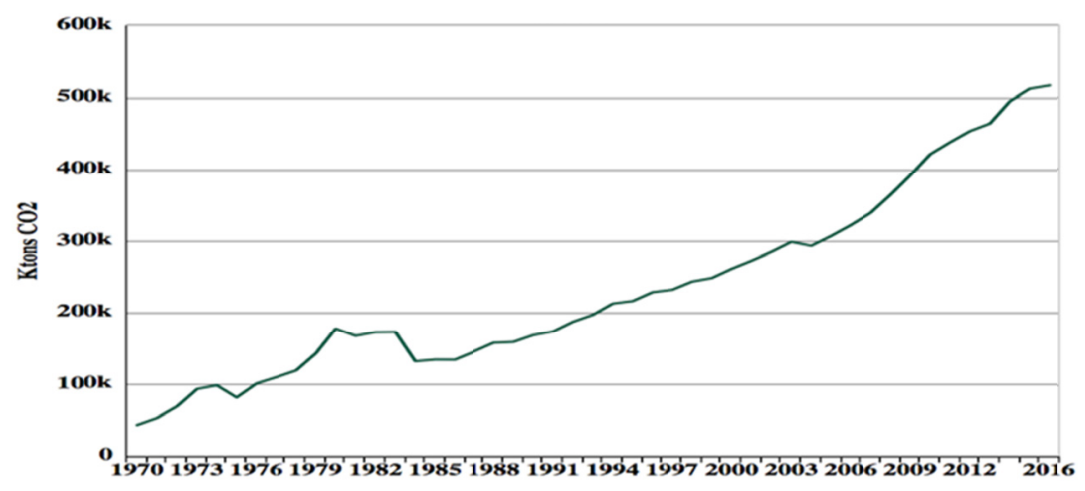

Figure 6. $\mathrm{CO}_{2}$ emission in the KSA between 1970 and 2016 in ktons (Knoema 2016)

One of the main causes of air pollution in the KSA is that a large part of the Arabian Desert is located in Saudi Arabia which features a very hot and humid climate. Therefore, the use of any type of transportation other than a cooled is arduous. People use big vehicles to persevere through the brutal atmospheres and climate changes. The big vehicles produces a significant amounts of nitrogen oxides, carbon monoxide, and other pollution that contribute to air pollution. Moreover, greater vehicles devour more gas and contaminate three to five times more than autos (EPA). In addition, the hot climate leads to a huge use of air conditioner. According to Demirbas et al., more than $70 \%$ of Saudi's electricity is consumed for air conditioning and cooling, and the summer demand is about twice the winter demand (Demirbas, Hashem et al. 2017). Since Fossil fuels are used to generate the electricity in KSA, the use of air conditioner causes air pollution.

The desalination plants are counted as an important cause among the causes generated air pollution in the kingdom. There are thirty desalination plants in the KSA and more than $60 \%$ of the consumed water is provided from desalinated sea water (Demirbas, Hashem et al. 2017). These plants cause air pollution since fossil fuels are used as power source to generate the large amounts of energy requested by these plants. Moreover, drinking water demand increases year after year and desalinated water consumption increases approximately $14 \%$ per year which aggravate the air pollution.

\subsection{Water Pollution}

The Kingdom suffers from water pollution caused by desalination, garbage and desertification. The desalination process of sea water is associated with the rejection of high concentration of waste brine from the plant, which causes water pollution. However, the rejected brine increases sea water temperature, salinity and turbidity and causes water currents which deteriorate the marine environment and causes fish to migrate. In addition, the use of different chemicals products and the waste chemicals generated in the desalination process cause toxic effect on fish and marine life. According to Saudi special environmental group, 50.21\% of the Saudi Arabia water is polluted. Moreover, the throw of the garbage without treatment and the water used in different oil companies to produce chemical products in the sea are responsible on the water pollution. On the other hand, the desertification, which eliminates the surface water and groundwater resources, is counted among the causes of water pollution in the Kingdom.

\subsection{Land Pollution}

Saudi Arabia has the eighth biggest refinery capacity in the world. The heavy operations related to exploration, production, processing and transportation of oil in the Kingdom of Saudi Arabia create a potential environmental threat of soil contamination. Hence, the mining process uses heavy metals and many toxic chemicals which leak out into the soil and lead to soil contamination. In addition, mining requires a lot of surface, drilling and excavation which degrades the land by disturbing its soil structure. Oil refineries release hazardous gases into the atmosphere, produce large quantities of waste water and solid waste that has a high content of petroleum derived hydrocarbons and heavy metal such as vanadium, zinc, chromium (total), iron, nickel, copper (Reinecke, van Wyk et al. 2016). High concentration of heavy metals can threaten human health and groundwater contamination. Moreover, Oil leakages from pipelines, oil wells, or underground storage tanks and the improper disposal of oil wastes could lead to soil contamination as well as surface and groundwater contamination.

\section{Renewable Energy Resources in the Kingdom}

The world is looking very seriously in the future for a clean energy resources such as renewable energy. Electricity demand in Saudi Arabia is anticipated to grow from $40 \mathrm{GW}$ up to $120 \mathrm{GW}$ between years 2010 and 2028 (Faruqui, 
Hledik et al. 2011, Baras, Bamhair et al. 2012). This will contribute to the projected increase in hydrocarbon use from 3.4 million barrels of oils (MBOE) equivalent per day to 8.3 MBOE in the same period. In order to meet the needs of a rapidly growing population and economy, meet the peak-load demand during the summer months and contribute to the national grid, Saudi Arabia needs more energy resources for electricity generation and desalination. The Kingdom of Saudi Arabia, guided by the goals set out in vision 2030, is undertaking an ambitious plan to increase the share of renewable energy from Saudi energy production and to reduce its long-term dependence on oil. The country has set a target of deploying $9.5 \mathrm{GW}$ of wind and solar capacity by 2023 (Bellini 2019). In addition, the Saudi government aims to increase its renewable energy production to $60 \mathrm{GW}$, including 40 GW from solar energy and 20 from wind and other sources by 2030. In 2019, twelve pre-developed projects with a total capacity of up to $3.1 \mathrm{GW}$ were expected to be tendered, while planning to complete the preliminary development of projects totaling $13 \mathrm{GW}$ by the end of this year. The current and planned situation of renewable energy in the kingdom are presented here.

\subsection{Solar Energy}

Solar energy has long been considered as a promising resource to produce energy. Saudi Arabia is one of the most fortunate countries of the sun, it has the longest sunshine hours with an average of 8.9 hour/day of sunshine and highest solar radiation intensity in the world with an average horizontal solar radiation of $6474 \mathrm{Wh} / \mathrm{m} /$ day (Rehman, Bader et al. 2007). Figure 7 presents the solar irradiation intensity across the Kingdom of Saudi Arabia between 1999 and 2013. It can be seen that the high potential of solar irradiation has been registered across most provinces, it ranges from about 6000 to over $7000 \mathrm{Wh} / \mathrm{m}^{2} /$ day. The highest potential has been registered mainly in Tabuk and Asir. A study was conducted by Erica et al. (Zell, Gasim et al. 2015) to analyze the Global Horizontal Irradiance (GHI), Direct Normal Irradiance (DNI), and Diffuse Horizontal Irradiance (DHI) data, based on one-minute measurements. These measurements were recorded in thirty stations distributed across the Kingdom covering the period from October 2013 to September 2014. Results showed that the annual average daily GHI ranged from $5700 \mathrm{Wh} / \mathrm{m}^{2}$ to $6700 \mathrm{Wh} / \mathrm{m}^{2}$, whereas higher values are registered inland and lower values are registered along the coasts. These results, which is of particular interest to photovoltaic installations, indicate that installation of photovoltaic would perform very well in the kingdom. Annual average daily DNI ranged from about $4400 \mathrm{Wh} / \mathrm{m}^{2}$ to over $7300 \mathrm{Wh} / \mathrm{m}^{2}$, whereas the highest values and clearest skies were registered in the northwest part of the country. These results, which is of particular interest to concentrating solar thermal installations, indicate that installation of concentrating solar thermal would perform very well. A review of the photovoltaic system for 32 sites of solar resources across KSA using three modes of a sun tracking system has been done by (Almarshoud 2016). Alharthi et al, conducted a study to analyze the solar potential in four different cities in the Kingdom, Riyad, Hafar Albatin, Sharurah and Yanbou (Alharthi, Siddiki et al. 2018). The obtained results showed that the GHI values are high at all of studied sites with relatively low variability and the highest annual average daily total of GHI and DNI of solar radiation was registered in Sharurah by $6682 \mathrm{Wh} / \mathrm{m}^{2}$ and $6207 \mathrm{Wh} / \mathrm{m}^{2}$, respectively. In addition, Silica, used in PV cells fabrication, is found in abundance in the white rock/sand with the highest ratio of $99.5 \%$ in the Kingdom because it is mainly a desert landscape (Elani and Bagazi 1998). Therefore, the solar energy has a brilliant future and it can be a viable source of energy generation in the Kingdom. 


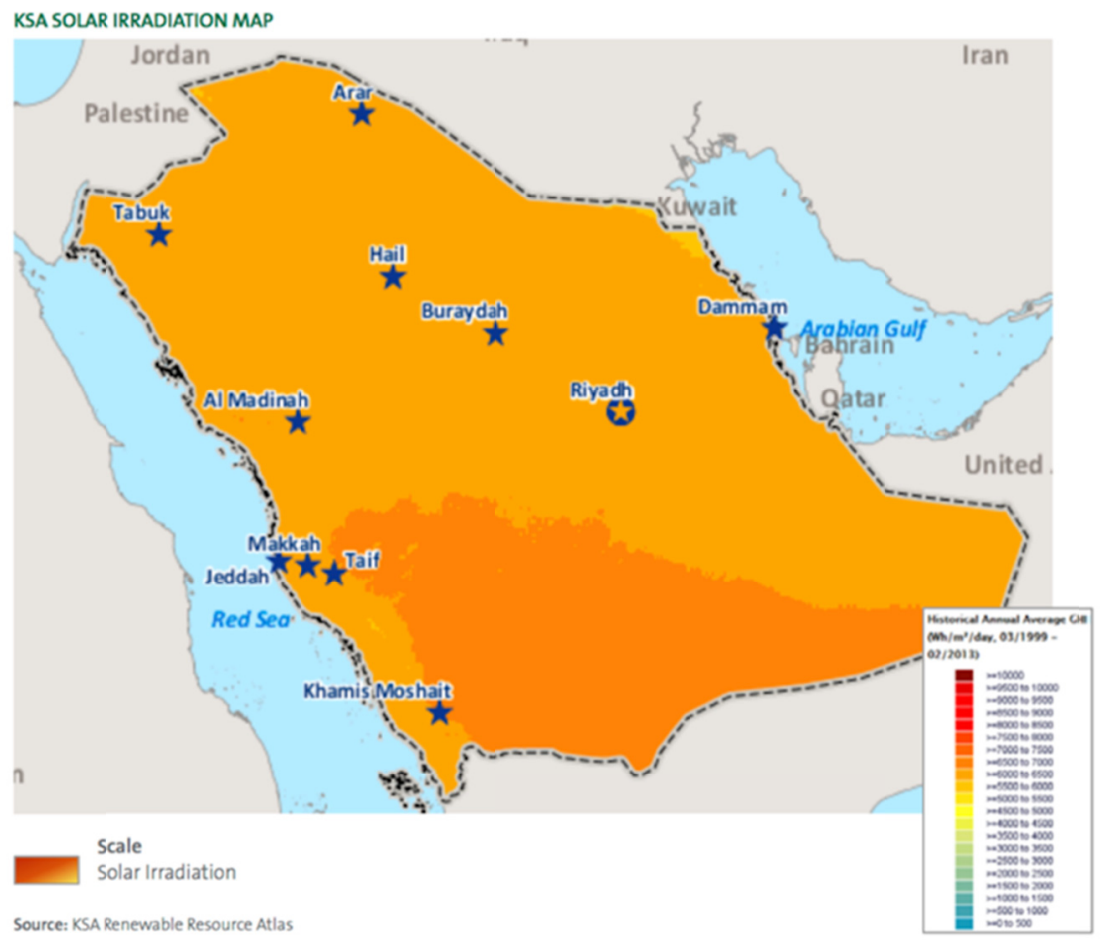

Figure 7. Solar irradiation across the Kingdom of Saudi Arabia

\subsection{Wind Energy}

Wind energy refers to the process of creating electricity by using the wind or air flows to generate electricity. It is a mature and a cost effective source of energy generation around the world with global capacity reaching over $600 \mathrm{GW}$ in 2018 ((IRENA) 2019). Since wind speeds vary based on geography, topography and season, some locations are better suited for wind energy generation than others.

Many studies have been done by researchers to estimate the potential of wind energy in different sites in the Kingdom of Saudi Arabia. A study was conducted by Rehman in 2004, to analyze the wind potential in five costal locations in KSA based on 14 years of wind data between 1970 and 1983(Rehman and Ahmad 2004). Results indicated that among the sites analyzed, Yanbo is the best sites to install wind turbines and Dhahran is the second best location. A study has been conducted by Al-Abadi to analyze the wind data collected in five sites in the KSA, Dhulum, Arar, Yanbu, Gassim and Dhahran (Al-Abbadi 2005). Results showed that Dhulum and Arar are suitable for wind energy application and Yanbu and Dhahran are suitable for grid connected wind energy generation. Another study has been done by Baseer et al. in 2015 to analyze the characteristics of wind speed in Jubail Industrial City located in the Eastern province of the Kingdom at three different heights (Baseer, Meyer et al. 2015). Results showed that the mean wind speeds were $3.34,4.79$ and $5.35 \mathrm{~m} / \mathrm{s}$ at $10 \mathrm{~m}, 50$ and 90 $\mathrm{m}$ respectively and the availability of wind speed above $3.5 \mathrm{~m} / \mathrm{s}$ was more than $75 \%$. Alharthi et al. analyzed the wind data in four different cities in the Kingdom of Saudi Arabia, Riyadh (middle of the country), Hafar Albatin (Northeast region), Sharurah (South), and Yanbu (West coast) (Alharthi, Siddiki et al. 2018). Results showed that the availability of wind speeds above $10 \mathrm{~m} / \mathrm{s}$ was $41 \%$ of the time at Yanbu followed by $27 \%$ at Hafar Albatin, $22 \%$ at Sharurah, and $14 \%$ at Riyadh at $80 \mathrm{~m}$ for the entire year. In addition, the highest annual mean wind power density was registered in Yanbu city with $833.78 \mathrm{~W} / \mathrm{m}^{2}$ at the height of $80 \mathrm{~m}$, which indicates that Yanbu is the best suitable site to generate electricity from wind. The Kingdom aims to produce $10 \mathrm{GW}$ of wind energy, creating more than 7,500 jobs and contributing more than 15 billion USD to Saudi Arabia's Gross Domestic Product by 2025 (Power 2018). The shift toward renewables is also accompanied by a push to diversify the economy from oil and gas, feed internal demand, and look at exporting renewable energy in the long-run.

\subsection{Geothermal Energy}

Geothermal energy is a form of thermal energy that has its origin in radioactive decay of various minerals inside the Earth's core. Since the water is replenished by rainfall and the heat is continuously produced inside the Earth, geothermal energy is considered as a renewable energy. Geothermal energy can find its way to the surface in the 
form of volcanoes and fumaroles, hot springs and geysers. Geothermal energy can be used in many forms such as direct use, electricity generation, space heating, heat pumps, greenhouse heating, and industrial usage. Geothermal resources have been classified based on their reservoir temperatures into low, intermediate and high enthalpy resources. Electricity generation is the most important form of utilization of high-temperature geothermal resources while low to medium resources are better suited for non-electric (direct) application resources. Electricity generated through geothermal systems are cost effective compared to other renewable energy sources and the land requirement for geothermal is the least among other renewables (Chandrasekharam, Lashin et al. 2015).

The kingdom of Saudi Arabia, has a plentiful resource of geothermal energy, mainly located at the western and southern parts. Saudi Arabia is among the most geothermally active countries in the Middle East. These resources are in relation with the general tectonic activity of the red sea and associated with a series of volcanic rocks and ridges. The geothermal power plants are not yet installed in Saudi Arabia, some direct-use low-grade geothermal applications are already installed in the ten last years as well as the refreshments and swimming pools that are already constructed in Bani Malik in Jizan area (Chandrasekharam, Lashin et al. 2015).

The geothermal resources of Saudi Arabia can be categorized as the following (Hussein, Lashin et al. 2013):

- Low enthalpy resources (sedimentary aquifers): the temperature is less than $125^{\circ} \mathrm{C}$. These resources are represented by deep-seated aquifers encountered in thick sedimentary basins and there are located in the eastern part of the Kingdom. Deep drilled wells are required to get access to these resources.

- Medium enthalpy resources (hot springs): the temperature lies between $125^{\circ} \mathrm{C}$ and $225^{\circ} \mathrm{C}$. These resources are located in the western and southwestern coastal parts and represented by the shallow hot springs of hot surface water. However, They are unconfined targets with direct accesses to the subsurface hot anomalies through an open network of active faults and fractures (structure control).

- High enthalpy resources (basaltic lavas, Harrats): the temperature is greater than $225^{\circ} \mathrm{C}$. These resources are represented by volcanic eruptions, mainly basaltic in composition, that extend along the coastal part of the Red Sea at the western of Saudi Arabia. The country has approximately $80,000 \mathrm{~km}^{2}$ of lava fields, known as Harrats.

The promising geothermal energy potential in the KSA is located in the Jizan province, which includes a number of structural-related hot springs with surface temperature from $46{ }^{\circ} \mathrm{C}$ to $78{ }^{\circ} \mathrm{C}$ (Lashin and Al Arifi 2014). The geological formations of Jizan include the Precambrian, the Quaternary igneous and sedimentary formations (Figure 8) (Lashin and Al Arifi 2014). Regarding the geothermal potentiality of Jizan area, three promising geothermal locations are found (Lashin, Al Arifi et al. 2015):

- Al-Ardah area: it is located at the East of Abou Arish. 7 hot springs have been found;

- Al Khouba (Lashin and Al Arifi 2014): it is located at the South-Eastern part of Jizzan and it is characterized by one main hot spring of high surface temperature up to $78^{\circ} \mathrm{C}$ with a good flow rate. It has been found that the heat flow, discharge enthalpy and subsurface temperature are $144 \mathrm{~mW} / \mathrm{m}^{2}, 318 \mathrm{~kJ} / \mathrm{kg}$ and $133^{\circ} \mathrm{C}$ respectively. The estimated geothermal potential is $17.847 \mathrm{MWt}$ providing a reservoir area of $1.125 \mathrm{~km}^{3}$.

- Bani Malik: it is located at the Northeast part of Jizzan and it characterized by a very complicated-topographic area. One hot spring of low-surface temperature $\left(45^{\circ} \mathrm{C}\right)$ has been found. 


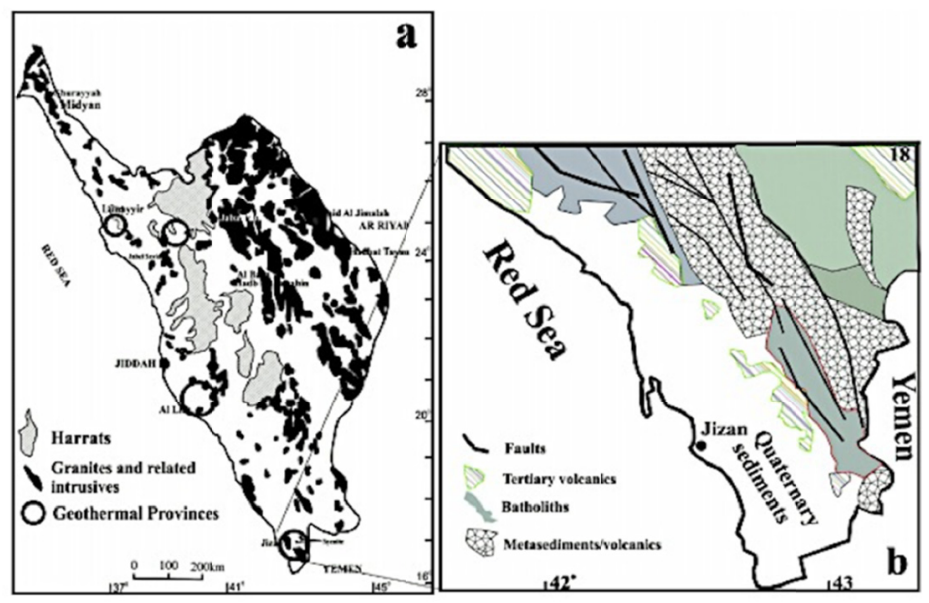

Figure 8. Western Saudi Arabia shield (a) showing the Harrats, granites and related intrusive and geothermal provinces and (b) the regional geology and structure of Jizan (Genna, Nehlig et al. 2002)

The first study on geothermal energy potential in Al-Lith and Jizan sites has been conducted in 1980. According to this study, it has been found that the ranges of reservoir temperatures are between $130-220{ }^{\circ} \mathrm{C}$ and heat flows are between $120-210 \mu \mathrm{W} / \mathrm{m}^{2}$. It has been estimated that the wet geothermal system can generate about $23^{*} 109$ $\mathrm{kWh}$. In addition, based on the reservoir characteristics and the thermal properties, the western Saudi Arabian shield encloses a large number of pre-and post-orogenic high radioactive granites with very high generating capacity from 15 to $134 \mu \mathrm{W} / \mathrm{m}^{3}$. According to this study, this granite can generate about $160 \times 1012 \mathrm{kWh}$ of electricity.

Wadi Al-Lith: it has been indicated that the subsurface temperature, heat flow and discharge enthalpy are $136{ }^{\circ} \mathrm{C}$, $183 \mathrm{~mW} / \mathrm{m}^{2}$ and $219 \mathrm{~kJ} / \mathrm{kg}$, respectively. The stored heat energy is $1.713 * 10^{17} \mathrm{~J}$ (rock and fluid) and a geothermal reserve potential of $26.99 \mathrm{MWt}$ (megawatts thermal) (Hussein, Lashin et al. 2013).

\subsection{Hydropower Energy}

The hydropower generation sector is overlooked and undermined in Saudi Arabia. The intensity and the frequency of rainfall are rare but they generate significant flash floods with huge amounts of surface water which, is very important for the temporary storage of water. This stored water could be a hydropower energy source for power generation. Many dams are existed in the Kingdom, there were 16 dams before 1975 and it raised to 230 in 2006 operating in twelve regions with a storage capacity of 850.33 million cubic meters and to 482 in 2014 with a storage capacity of 2.08 Billion cubic meters (Obaid 2015). In addition, 52 dams are under construction, ten of them are big dams which increase the storage capacity to 2.5 Billion cubic meters. Figure 9 displays the existing dams with their purposes located in different regions in the Kingdom. The largest dam in the Kingdom is the King Fahd dam (previously Wadi Bisha dam) located in Asir Region of southwestern of Saudi Arabia and it is the second largest concrete dam in the Middle East. The building of these dams aims to protect villages against the flooding that could threat them, to provide water irrigation and to increase of subterranean water reserves and the provision of potable water. According to the Ministry of Electricity and water, the utilized rainwater in the Kingdom does not exceed $10 \%$ of its annual precipitation.

Studies showed that the Kingdom can install combined capacities of at least 170MW of hydropower at existing dams and streams, generating around $745 \mathrm{GWh}$ of electricity every year (Obaid 2015). Techno-economic analysis studies are required to estimate the potential and the performance of this sector and to develop it in order to use as a clean source for power generation. 


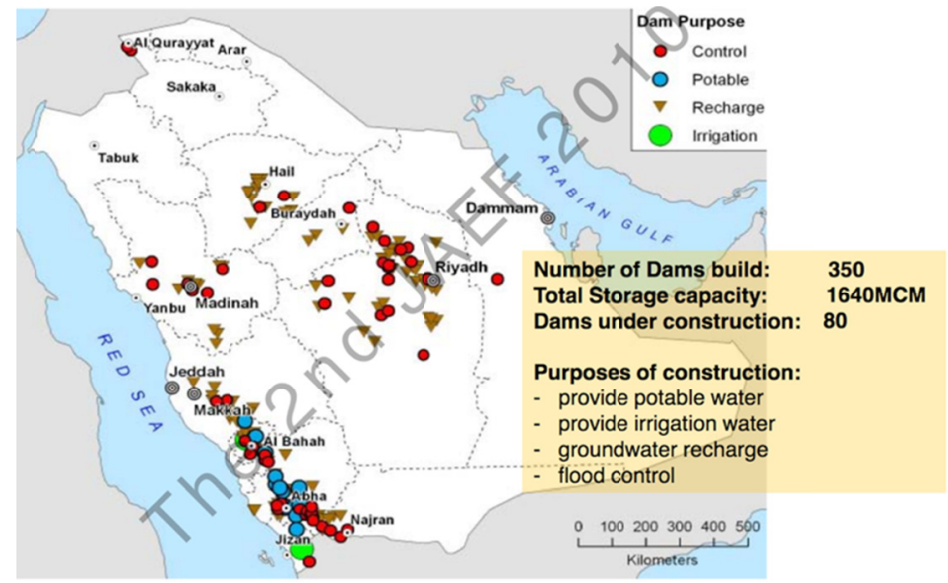

Figure 9. The existing dams with their purposes (AL-Saud 2010)

\section{- Municipal solid waste (MWS)}

Waste is a renewable energy source like wind and solar. The efficiency management of waste by recycling and generation of energy, such as waste to energy, can play an important role in decreasing the harmful effects of waste on environment and reducing the workload on hydro, solar and wind energy. According to (Nizami, Rehan et al. 2015), the rate of municipal solid waste (MSW) generation in KSA is $15.3 \mathrm{Mt} / \mathrm{y}$ with the average rate of 1.4 $\mathrm{kg} / \mathrm{capita} / \mathrm{d}$. Figure 10 displays the solid waste generated in different cities located in KSA. It can be observed that the highest waste generated is registered in the capital Riyad with a percentage of 33\% followed by Jeddah with a percentage of $22 \%$. The two major components in the MWS in Saudi Arabia are mainly, organic waste (food and paper) and plastics. Furthermore, the immense use of food is the main source of organic waste, whereas the enormous use of disposable stuff is the main source of plastic waste, especially during pilgrims period and the holy month of Ramadan. However, some other components are found in waste such as textile (6.4\%), glass (4.6\%) and minerals (8.1\%) (Khan and Kaneesamkandi 2013). The overall composition of municipal solid waste generated in KSA are presented in Figure 11. The municipal solid waste is collected from individual or community bins and disposed of in landfills or dumpsites. However, recycling, reuse and energy recovery processes are at an early stage. An active informal sector extracts papers, plastics and metals from municipal waste and drives the recycling process which has a rate change between $10-15 \%$.

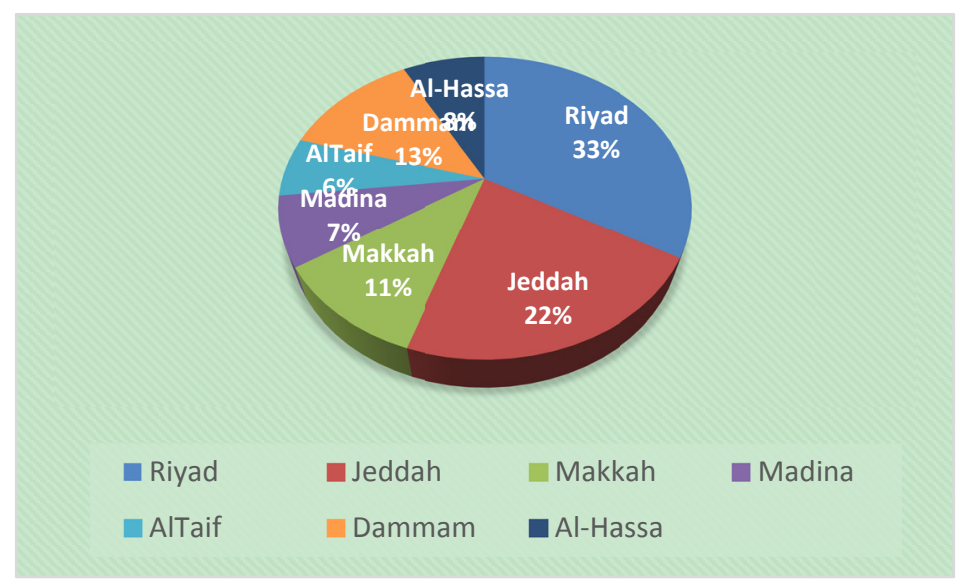

Figure 10. Solid waste production in different cities of KSA (Tolba and Saab 2008, Ouda, Cekirge et al. 2013) 


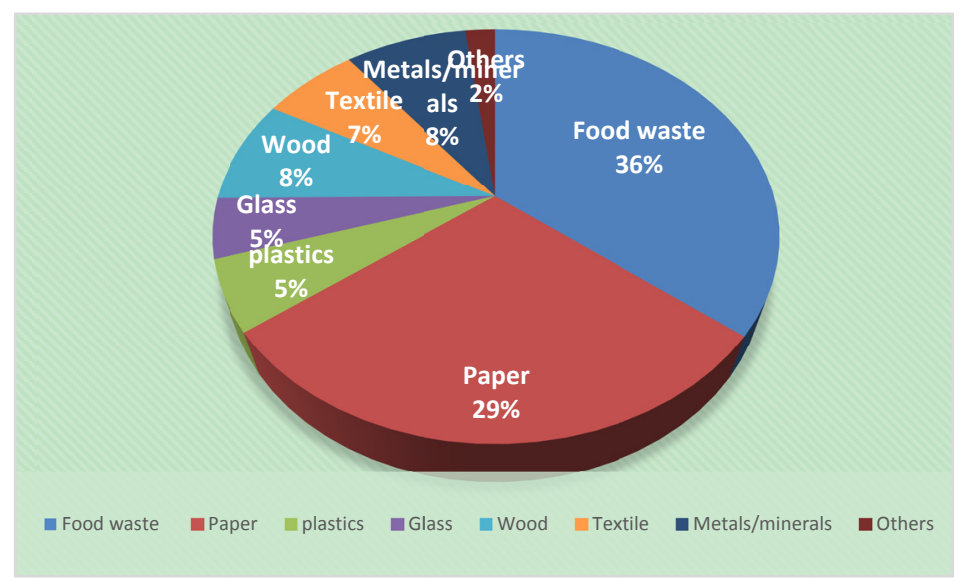

Figure 11. Composition of municipal solid waste produced in KSA (Tolba and Saab 2008, Ouda, Cekirge et al. 2013)

Many serious negative environment issues can be caused by incompetent solid waste management such as land and water pollution, infectious disease and biodiversity losses. Therefore, an efficient MSW management by recycling, reusing and energy recovering can reduce the amount of waste disposable and the GHG emissions, decrease the pollution, and produce energy such as Waste to energy (WtE).

Waste to energy (WTE) is the technology of generation energy from the primary treatment of food or the processing of waste into a fuel source. It provides a cost effective solution to both energy demand and Municipality solid waste (MSW) disposal problems (Ng, Mao et al. 2017). There are many different technologies of WTE such as incineration, pyrolysis, gasification, plasma arc gasification, bio-methanation and refuse derived fuel. In order to add a significant value to sustainable waste management in KSA, a study has been conducted by (Ouda, Raza et al. 2016) to examine the potential of power generation using incineration and refuse derived fuel, which are Waste to Energy technologies, from 2012 to 2035. Results indicated that the potential of power generation from the WTE technologies is huge and it can rebound power generation from renewable sources. In addition, it has been found that the bio-methanation technology could be the most suitable WTE technology for the kingdom due to its high efficiency, its lowest annual capital and operational cost, and the availability of huge food waste volume. However, the incineration technology can be an efficient solution since it has higher efficiency and lower operational cost but it has some limitation factors such as the need for treatment of air and water borne pollutants and ash with in the incineration facility.

A study on the current status of waste disposal system in KSA has been carried out by (Anjum, Miandad et al. 2016). It has been found that the anaerobic digestion may be used in the treatment of the organic fraction of MWS and the plastic waste can be treated by the pyrolysis technology. The anaerobic digestion generates the methane gas that can be converted to liquid fuel while the pyrolysis produces many value-added products, such as fuel oil and char.

A study to assess the potential of waste-based biorefinery and recycling as a source of renewable electricity production and a solution to current waste landfill problems in Makkah city has been carried out by (Nizami, Shahzad et al. 2017). Results indicated that the development of waste-based biorefinery in Makkah along with recycling will benefit the country's economy with total net revenue of 758 million SAR based on electricity generation (288.5 million SAR), and landfill diversion (530.4 million SAR). In addition, waste-based biorefinery in Makkah city can save 1.95 million barrels of oil and 11.2 million MCF of natural gas, with a total cost savings of 368.8 and 116.6 million SAR respectively.

An assessment of biodiesel production from the fat fraction of the municipal solid waste in the Kingdom of Saudi Arabia for energy generation under three different scenario has been done by (Rehan, Gardy et al. 2018). The three different scenario are: (S1) KSA population only in 2017, (S2) KSA population and pilgrims in 2017, and (S3) KSA population and pilgrims by 2030. Results showed that that S1, S2, and S3 scenarios could produce around 1.08, 1.10 and 1.41 million tons of biodiesel with the energy potential of 43423, 43949 and $56493 \mathrm{TJ}$ respectively.

An investigation of the current construction and demolition (C\&D) debris management practices in KSA has been done by (Blaisi 2019). This study identified economical, regulatory and technical solutions to implement 
better $\mathrm{C} \& \mathrm{D}$ management practices such as development of clear regulations to encourage contractors to recycle construction and demolition waste, implementing recycling programs and building waste management recycling facilities.

The above studies show that Saudi Arabia has an important potential of waste management as renewable energy source.

\section{Energy Plan in the Kingdom 'Vision 2030}

The energy sector in Saudi Arabia is entirely controlled by the Ministry of Energy, Industry, \& Mineral Resources (MEIM). The role of this governmental agent is to supervise and monitor the performance of the energy sector in the kingdom. It is also a legislature to control energy market and to preserve natural resources. MEIM supervises three main bodies which are considered the cornerstones of the electric power industry in the kingdom. These bodies are the Saudi Electricity Company (SEC), the Electricity \& Cogeneration Regulatory Authority (ECRA), and the King Abdullah City for Atomic and Renewable Energy (KACARE). The Saudi Electricity Company (SEC) is a governmental company ( $80 \%$ owned by the government) responsible for generating, transmitting, and distributing electricity all over the kingdom. The company is responsible for providing all the villages with electric power although the rough geography of the kingdom which contains large areas of desert and long series of mountains. Although the direct finance support from the government, the company incurred net losses of 1214000 SR and 1489000 SR for Q1 2018 and Q1 2019, respectively (Argaam 2019). The Electricity \& Cogeneration Regulatory Authority (ECRA) is responsible for regulating and fostering development of the electricity and water desalination industry in KSA. King Abdullah City for Atomic and Renewable Energy (KACARE) is responsible for developing technical knowledge, skills, and expertise in the field of atomic and renewable energy. The energy constitutes an important part of the Kingdom' vision 2030. There are four key considerations, including energy efficiency programs, energy prices, diversification of energy sources, and net metering regulations (Kabbara 2018):

- Energy efficiency programs: Encompasses the three sectors, transport, industrial and residential. In the residential sector, the program aims to update the building code and mandate standards specifications for thermal insulation materials, computers, air conditioners, appliances, lighting, etc. In the transport sector, it aims to develop a fuel economy label for light duty vehicles, introduced energy efficiency standards for tires and regulated energy efficiency of heavy duty vehicles. In the industrial sector, it set up energy intensity targets for existing and new plants.

- Diversification of energy use: The energy use in the Kingdom has been nominated by the oil. The Aramco Saudi's company has a plan to double the use of natural gas in the processing capacity and to raise the contribution of the energy mix for power generation from $50 \%$ to $70 \%$ by 2030 . The energy mix for power generation includes the combination of the use of various primary energy sources such as fossil fuel, nuclear energy and renewable energy to generate electricity. One of the main goals of Vision 2030 is to bring long term economic stability in the Kingdom of Saudi Arabia, this will be achieved by the National Renewable Energy Program which aims to increase the production of energy from solar and wind power. The total of generated energy target is estimated to be $3.45 \mathrm{GW}$ by the year 2020 and $9.5 \mathrm{GW}$ by 2023 and $2.8 \mathrm{GW}$ nuclear power plants. Moreover, the National Renewable Energy Program has three main projects to achieve its aim: a solar PV plant project of $300 \mathrm{MW}$ in Sakaka, and two more projects of 2,400 MW wind energy plants in Midyan and Dumat Al-Jandal. Additionally, more projects will be added in the next few years to create more opportunities for cooperation between public and private partnerships. Figure 12 presents the planned solar PV, Wind and concentrated solar power projects in KSA.

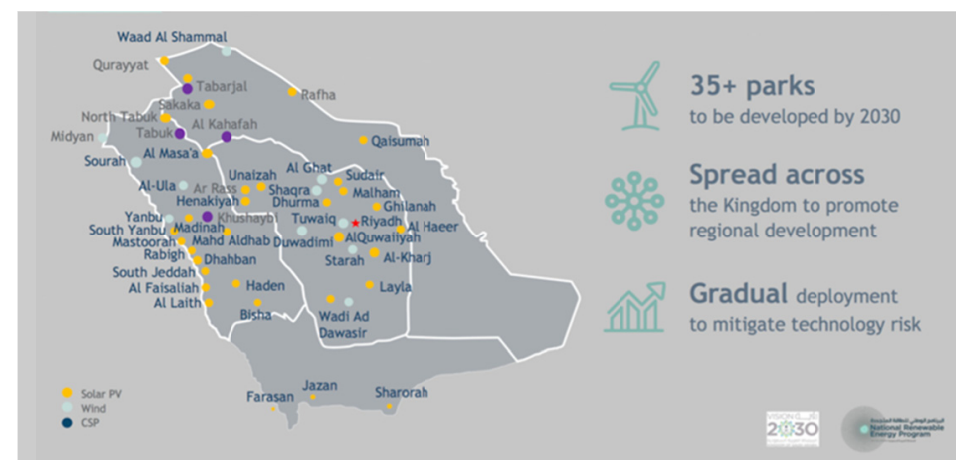

Figure 12. Planned renewable energy projects in KSA (Office-REPDO 2019) 
- $\quad$ Net-Metering Regulations (Figure13): in order to encourage private investment in renewable energy sector and to accelerate private sector investment in small scale renewable energy applications, the Electricity and Cogeneration Authority issued a regulatory framework for electricity consumers to operate their own solar small scale system $(<2 \mathrm{MW})$, to generate their own need of electricity and to export unused power to the national grid.

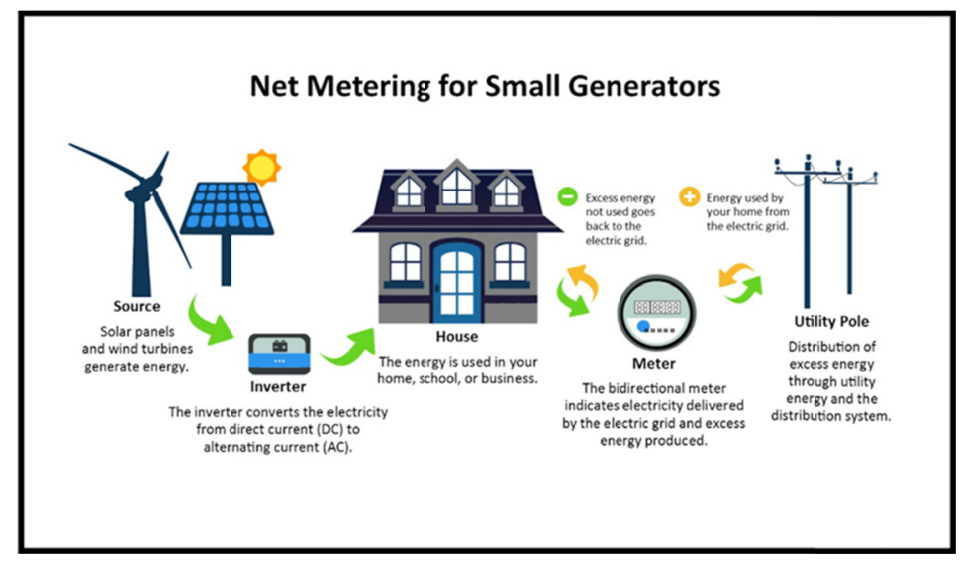

Figure 13. Net metering system working principle

- Energy Prices: Since price control is used as a method of controlling electricity demand in the short-term and in order to slow down the growth demand of domestic energy in the Kingdom, the Saudi government has raised the price of domestic energy prices and called for a greater efficiency. The government increased the price of oil and gas. Between 2016 and 2018, Natural gas prices increased by 67\% for utilities and by 133\% for industry; gasoline and diesel prices increased by $240 \%$ and $80 \%$ respectively for the transport sector; and liquid fuels increased by $60 \%$ for the utilities. This increasing of the price of oil and gas necessitated an increasing in the price of electricity by $260 \%$. The Electricity and Cogeneration Regulatory Authority has announced an increase in the price of electricity. From January 2018, the residential users started to pay $18 \mathrm{ha} / \mathrm{kWh}$ compared to 5 or $10 \mathrm{ha} / \mathrm{kWh}$. The effect of the increasing of the electricity tariffs is an increasing in the monthly electricity bill but it will encourage residential users to decrease the energy consumption and to use renewable energy such as small-scale solar power. In addition, another policy based on increasing of the electricity tariffs during peak times which coincides with peak solar PV output could be applied.

\section{Challenges to the Development of Renewable Energy in KSA}

The implementation of renewable energy technologies in KSA, that will support the sustainable development, faces many challenges. Some of the main technical and economic/managerial impediments for the implementation and development of renewable energy in KSA are:

\subsection{Technical Barriers Faced the Implementation of Solar Energy}

Several environmental stress factors such as temperature, humidity, UV radiation and dust affect the development and the implementation of solar energy in KSA.

\section{- Temperature}

Performance of solar cells depends on operation conditions such as temperature, light intensity and their output parameters such as output voltage, current and power. A study on the effect of temperature on the performance of a photovoltaic solar system in Eastern Nigeria has been done by (Ike 2013). The results showed that the output power dropped with the increasing of the ambient temperature. The climate of Saudi Arabia is marked by its typically harsh, dry desert with great temperature extremes. Figures 14 and 15 display the mean monthly high and low temperature in Makkah Al Mukarramah and Riyadh respectively. It can be noticed that the low temperature varies between $18^{\circ} \mathrm{C}$ and $28^{\circ} \mathrm{C}$ and the high temperature varies between $30^{\circ} \mathrm{C}$ and $45^{\circ} \mathrm{C}$ in $\mathrm{Makkah} \mathrm{Al}$ Mukarramah. In Riyadh, the low temperature varies between $9^{\circ} \mathrm{C}$ and $29^{\circ} \mathrm{C}$ and the high temperature varies between $20^{\circ} \mathrm{C}$ and $43.6^{\circ} \mathrm{C}$. Therefore, the high temperature recorded in Riyad and Makkah presents a significant barrier to the installation of PV panels in KSA. 


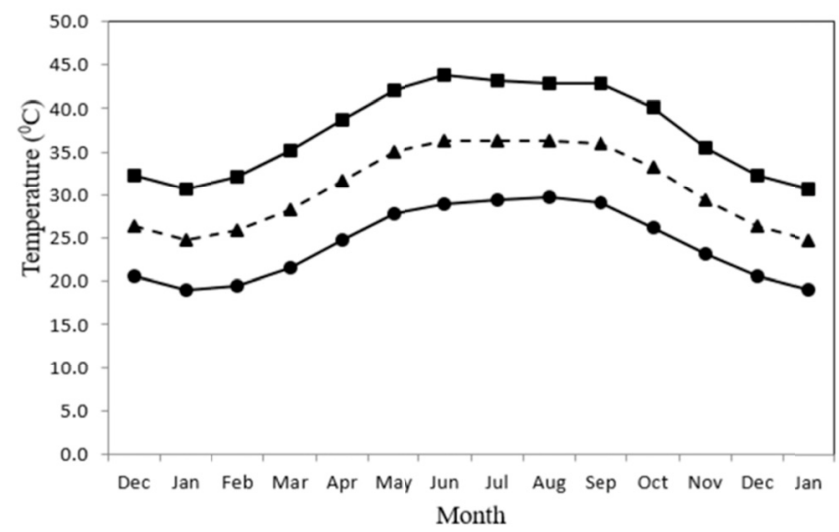

Figure 14. Mean Monthly, Mean Monthly Maximum and Minimum Temperature (1985-2016) in Makkah AL Mukarramah (Khan and Alghafari 2018)

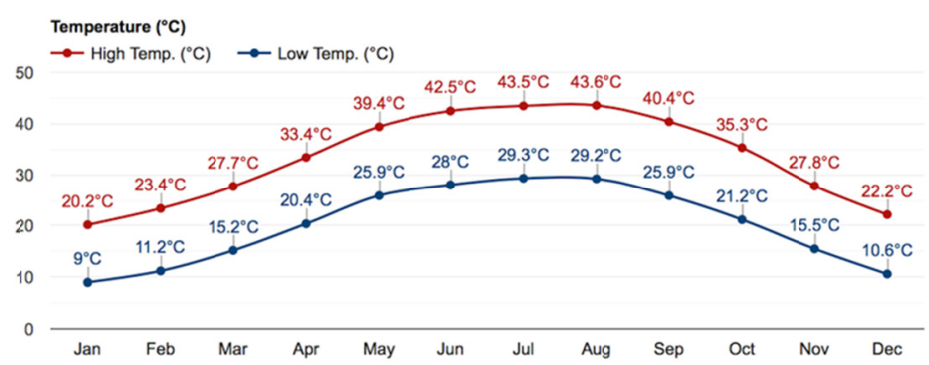

Figure 15. Mean Monthly Maximum and Minimum Temperature in Riyad (Atlas 2019)

UV rate:

A study on the impact of UV radiation on the Silicon PV system has been carried out by (Shamachurn and Betts 2016). Results indicated that UV radiation degrades polymeric encapsulates which causes power output loss and it affects the antireflective coatings applied on solar cells. Moreover, compared to a Si-devices exposed under the broadband spectrum light with higher total irradiance but lower UV content, it causes a greater ageing in a $-\mathrm{Si}$ devices. In addition, a changing in color of materials is caused by the UV degradation.

Figure 16 shows the average UV index in Riyadh and the UV index scale is shown in Figure 17. It can be seen that the lowest UV rate registered in Riyadh during December is 5, which is a medium rate. A high UV rate (6-7) has been registered during January and November, a very high UV rate (8-10) has been registered during February, March and October, and an extremely high UV rate has been registered during April, May, June, July August and September. It can be concluded that the high UV rate presents also a significant barrier to install PV systems in the KSA.

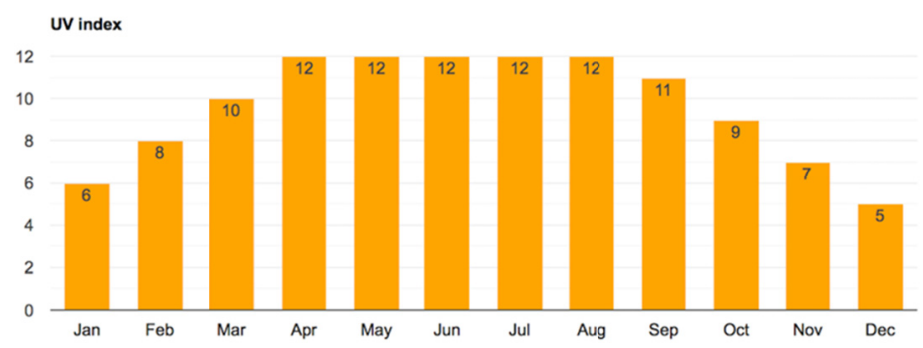

Figure 16. Average UV index in Riyadh, KSA (Atlas 2019) 


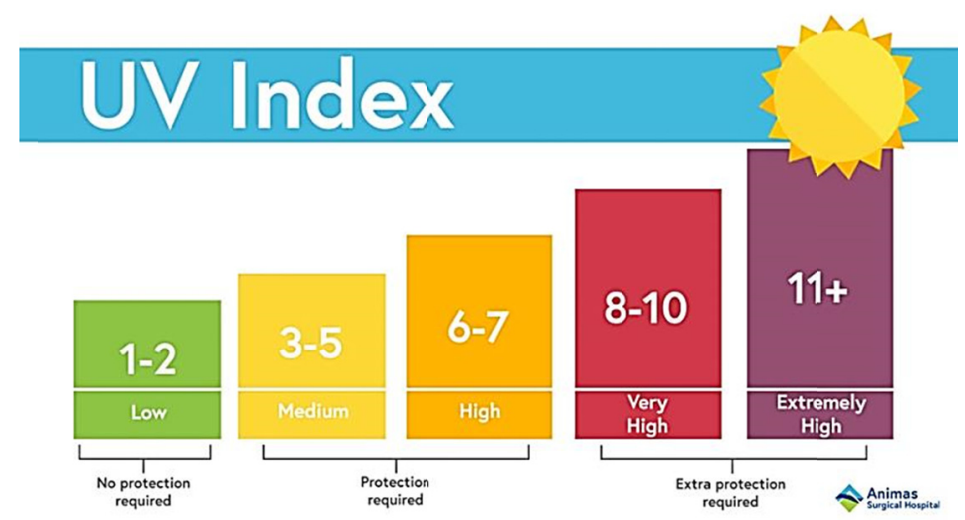

Figure 17. UV index scale (Agency 2017)

\section{- Humidity}

Many studies have been conducted on the effect of humidity on the performance of PV panel. A study on the effect of humidity on photovoltaic performance has been done by (Kazem and Chaichan 2015). Results indicated that an increasing of relative humidity drops the voltage of PV and an increasing of relative humidity from $67 \%$ to $95 \%$ reduced the current by $44.44 \%$. Panjwani and Narejo studied the effect of humidity ranges between 40 to $78 \%$ and they found that the PV power reduced from 15-30\% (Panjwani and Narejo 2014). Another study on the effect of solar flux and relative humidity on the efficiency of solar PV has been carried out by Omubo-pepple. Results showed that a decrease of relative humidity leads to increase the current, the output voltage and the efficiency (Omubo-Pepple, Israel-Cookey et al. 2009).

Figures 18, 19 and 20 present the mean monthly relative humidity in Dhahran (33\% -70\%), Riyadh (10\% -37\%) and Makkah Al Mukaramah (35\% -60\%). It can be noticed that the highest relative humidity has been registered in Dhahran while the lowest in Riyadh. Therefore, the effect of relative humidity could affect the implementation of $\mathrm{PV}$ in some cities in the Kingdom.

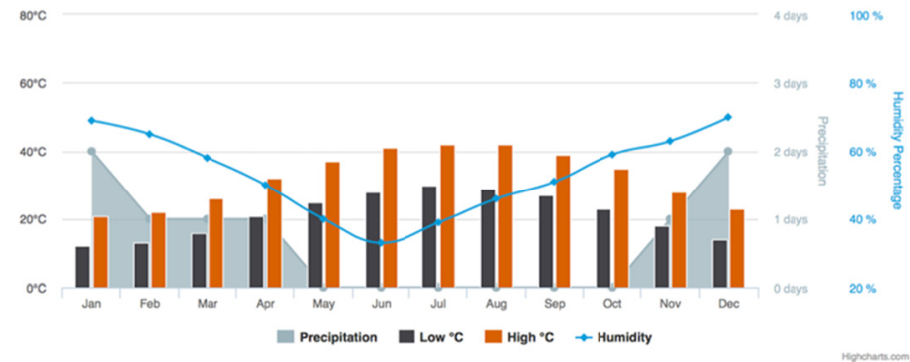

Figure 18. Mean Monthly Temperature, Mean Monthly relative humidity and Mean Monthly precipitation in Dhahran (Iamat 2019)

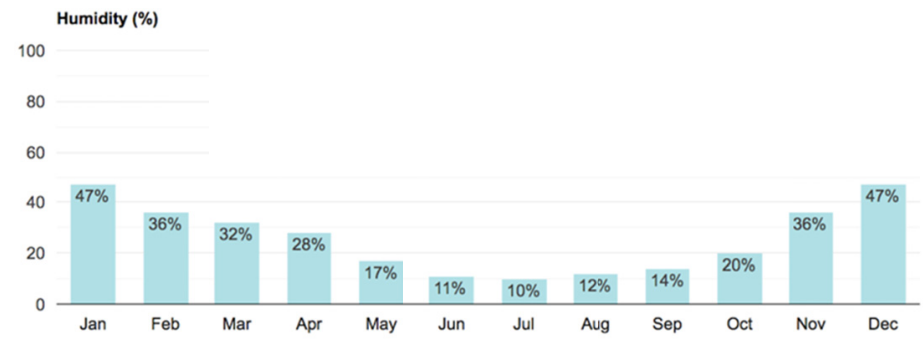

Figure 19. Mean Monthly Relative humidity in Riyad (Atlas 2019) 


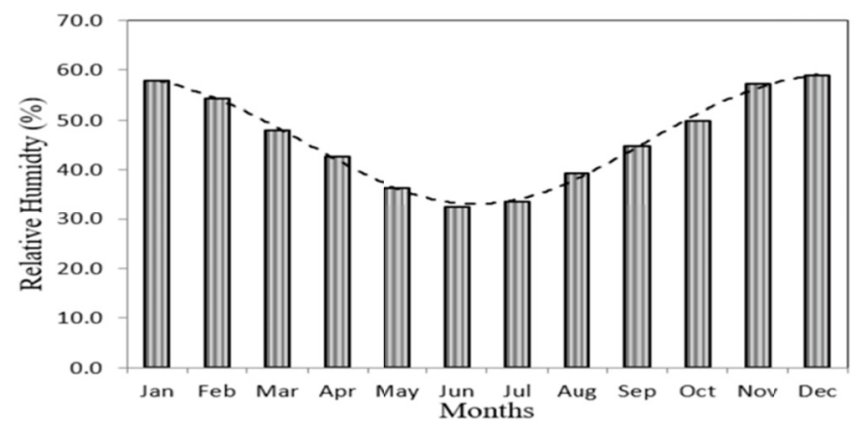

Figure 20. Makkah Al Mukkaramah Mean Monthly Relative humidity (1981-2015) (Khan and Alghafari 2018)

- Dust

The impact of dust on the PV panels has been carried out by many studies. A study on the impact of dust on solar system has been done by (Hottel 1942). Results showed the dust can cause a maximum of $4.7 \%$ degradation in collector performance. Another study has been carried out by Wakim on the impact of sand accumulation on PV system in Kuwait City after six days, showed a reduction of $17 \%$ in PV power (Wakim 1981). Dirk Goosen et al have conducted an experiment study on the effect of Aeolian dust deposition on PV cells (Goossens and Van Kerschaever 1999). Results showed that the deposition of fine Aeolian dust particles on the glazing of PV cells significantly affected the performance of such cells. Another study has been carried out by Sulaiman et al. (Sulaiman, Hussain et al. 2011) and it has found that the dust causes a reduction of $18 \%$ of the peak power generated.

Saudi Arabia is susceptible to storm and dust storms due to the desert, which covers more than $90 \%$ of the country, drought and meager vegetation cover. A thesis has been conducted by Labban on the analysis of dust activity for 25 cities across the Saudi Arabia for frequency of each type of dust (Labban 2015). Results revealed that the cities in the South and in the South-East experienced the most number of dust events and there were cities, experienced much fewer dust events than their neighbors in the same region caused by their altitude or surrounding topography. Moreover, it has been found that spring is the most dust prone season in the northern part whilst summer is the season when more dust events occurred in the southern part. The Riyadh city is exposed to dust storms several times in the year. A study has been carried out by Al-Tayeb and Jarrar and they found that the dust falling in Riyadh is around 220 tons $/ \mathrm{km}^{2} /$ year (Al-Tayeb and Jarrar 1993). Another study has been done by Basahy, and the results showed that the dust deposition rate in Riyadh is around 196-220 tons $/ \mathrm{km}^{2} /$ year (Basahy 1987). Therefore, the dust and dust storm also present a significant barrier to the installation of PV system in the Kingdom of Saudi Arabia.

\section{- $\quad$ Hail, heavy rain and high wind}

The high wind speed and the heavy rain can damage the solar panels or dislodged them for their spot. However, similar to hail, solar panels are typically tested by manufacturers to ensure that they can survive hurricanes.

\subsection{Technical Barriers Faced the Development of Wind Energy in KSA}

The dust presents a critical challenge faced the wind turbine project since dust is common where there is wind. The accretion of dust on the turbine rotors and blades causes changes in the aerodynamic properties of the airfoils, which results in decreasing of the power output and degradation of the performance of the wind turbine (Khalfallah and Koliub 2007, Fiore and Selig 2015). In addition, it causes a decreasing of longevity and an increasing of maintenance costs of the wind turbines. Wind turbines are also vulnerable to high wind speed and hurricane.

\subsubsection{Technical Barriers Face the Development of MSW Management}

Several barriers facing the development of MSW management such as:

- Lack of waste separation and waste management facilities and infrastructures in the country, in addition, lack of financial budget and resources for waste management in municipalities.

- Insufficient awareness among citizens and public attitudes towards waste: waste is valuable to people who sell recyclable material but it has not any value for citizens.

- Lack of familiarity with the economic opportunities associated with waste management. 
- Absence of legal and regulatory framework to identify and categorize waste type and to plan all process related to transport, treatment and storage.

\subsection{Economic/Managerial Barriers}

- Low price of natural gas: Natural gas is considered as a cleaner energy source than coal and oil in power generation. Saudi Arabia's holds the sixth largest natural gas reserves in the world and it is considered as a large producer of natural gas. Hence, the price at which natural gas is sold domestically in Saudi Arabia is one of the lowest in the world $(\$ 1.25 / \mathrm{mm} \mathrm{Btu}$ ) and therefore, it contributes to rapid increasing of its consumption (Alturki 2016). The natural gas could present a serious and a strong competitor of renewable energy, due to its consideration as a clean energy source, its availability and its lower price in the Kingdom.

- Missing legal and regulatory framework deters investors and impedes funding.

- The amount of revenue generated from renewable energy cannot be similar to that produced from oil, and this will affect the state's ability to provide for welfare distributions (Ratikainen 2017).

- The rareness of providing renewable energy education and training.

- Lack of a skilled workforce, knowledge, expertise and experience laborers in renewable energy.

- Due to the intermittent nature of solar energy and wind generation, it cannot be easily integrated and dispatched with the grid of a utility company (Patlitzianas, Doukas et al. 2006).

\section{Recommendations}

The initiatives of the Vision's 2030, stipulated by the Saudi government, are gearing towards efforts to achieve sustainable development goals. There is an intimate relation between renewable energy and sustainable development. Development can not be achieved without energy and sustainable energy is the cornerstone in sustainable development. Based on the analysis of the available renewable energy resources in the KSA, some recommendation are presented her to overcome the above barriers in order to expand the development of renewable energy sector:

- Increasing capital flows for R\&D which aims to develop renewable energy in the Kingdom and to find solutions to overcome the barriers to the development of renewable energy.

- Interest-free loans for purchase of renewable energy equipment.

- Municipal Solid Waste (MSW) management: an effective management of MSW requires a raising of public awareness that the waste, which they throw, has an important value, it is a raw material for other processes such as recycling, treatment and energy recovery. The government should work on the development of programs that spread awareness and knowledge to a wide audience through a variety of mass media and an organization of seminars. In addition, the private sector and governmental sector can play a crucial role by providing sufficient facilities related to different waste bins for proper household segregation as well as scheduled collection systems. Also, the integration of many waste management technologies such as pyrolysis, anaerobic digestion, waste recycling, WTE and value-added product (VAP) recovery. Moreover, the implementation of EPR (extended producer responsibility) which aims to bear the producer the responsibility of taking back, recycling and final disposal of their products and therefore decreases the environmental impacts of their products.

- Regulating to limit greenhouse gas emissions from power plants such an "Introducing Carbon Capture and Storage (CCS) " technology in power plants and industrial facilities in order to prevent the carbon dioxide from entering the atmosphere. The advantage of this technology is that up to $90 \%$ of the $\mathrm{CO} 2$ emissions produced from burning fossil fuel for transportation, electricity generation and industrial processes can be captured by it.

- Raising awareness on the importance and benefits of renewable energy by introducing and developing of Academic Curricula for Renewable Energy and increasing the scope of the study, degrees as well as schools dedicated to the fields of solar, wind and other exponents of renewable energy.

- Training for engineers and policy makers to plan, design, operate and maintain renewable energy technologies since skills and capabilities are fundamental to an effective development and use of renewable energy technology.

- A renewable portfolio standard (RPS) which is a regulation that requires an increasing production of energy from renewable energy sources. These policies can play an integral role in state efforts to diversify the energy mix, promote economic development and reduce emissions.

- Resource Mapping of Renewable Energy Sources should be undertaken by the government in order to entice the interest of entrepreneur in exploiting the potential. 
- Smart grid technologies: The fluctuations in renewable energy supply cause some mismatch between supply and demand. The smart grid technologies should be developed and deployed in order to support grid connections with renewable energy and enhance the use of renewable energy.

- Fossil fuel substitution by solar energy in desalination plants: The production of $1000 \mathrm{~m}^{3}$ of freshwater per day requires 10000 tons of oil per year (Kalogirou 2005). However the KSA is largest producer of desalinated water in the world. Therefore, the use of a solar energy in desalination plants can be critical part in reducing the consumption of fossil fuel and reducing GHG emissions.

\section{Summary}

The Kingdom of Saudi Arabia is highly rich in renewable energy resources including solar, wind, geothermal and hydropower. However, the country relies on fossil fuel to feed the energy demand and the share of renewable energy in the final consumption is very small. The transport and the industry sectors are by far the most energy-intensive in the country while the agriculture and the forestry sector is the lowest one. The country suffers from a high rate of pollution and it is among the highest polluted countries in the world due to heavily dependence on fossil fuel, climatic conditions, desalination plants, growth population and high energy demand. KSA set out the Vision' 2030 that aims to achieve sustainable development in its three dimensions, economic, social and environment. The sustainable energy presents an essential key for a successful sustainable development and therefore, the development of renewable energy can support the efforts aimed to attaining the SD Goals. However, The sector of renewable energy, in its current situation, faces many technical, economical gauntlets and challenges. The main impediments can be categorized into climate, lack of awareness of the importance and potential of renewable energy, and abundance of fossil fuels and its low price. Many actions has been taken by the Saudi government to decrease the energy consumption such as the increasing of electricity price. However, the country should take more actions such as Resource Mapping of Renewable Energy Sources, Renewable portfolio standards, developing of Academic Curricula for Renewable Energy, smart grid technologies, increasing R\&D in the field of renewable energy technologies and regulating to limit greenhouse gases emissions.

\section{References}

(IRENA), I. R. E. A. (2019). Renewable capacity statistics 2019. Abu Dhabi.

Agency, E. P. (2017). UV Index Scale. Retrieved from https://www.epa.gov/sunsafety/uv-index-scale-0

Al Garni, H., Kassem, A., Awasthi, A., Komljenovic, D., \& Al-Haddad, K. (2016). A multicriteria decision making approach for evaluating renewable power generation sources in Saudi Arabia. Sustainable Energy Technologies and Assessments, 16, 137-150. https://doi.org/10.1016/j.seta.2016.05.006

Al-Abbadi, N. M. (2005). Wind energy resource assessment for five locations in Saudi Arabia. Renewable Energy, 30(10), 1489-1499. https://doi.org/10.1016/j.renene.2004.11.013

Al-Tayeb, N., \& Jarrar, B. (1993). Dust fall in the city of Riyadh. Proceedings of the Industrial Air Pollution Symposium, Riyadh.

Alharthi, Y., Siddiki, M., \& Chaudhry, G. (2018). Resource Assessment and Techno-Economic Analysis of a Grid-Connected Solar PV-Wind Hybrid System for Different Locations in Saudi Arabia. Sustainability, 10(10), 3690. https://doi.org/10.3390/su10103690

Almarshoud, A. (2016). Performance of solar resources in Saudi Arabia. Renewable and Sustainable Energy Reviews, 66, 694-701. https://doi.org/10.1016/j.rser.2016.08.040

Alturki, F. M. (2016). Natural Gas and the vision 2030. Riyad, Jadwa Investment.

Anjum, M., Miandad, R., Waqas, M., Ahmad, I., Alafif, Z., Aburiazaiza, A., ...Akhtar, T. (2016). Solid Waste Management in Saudi Arabia. Applied Agriculture and Biotechnology, 1, 13-26.

Argaam. (2019). Saudi Electricity widens Q1 loss by 23\%. Riyad.

Atlas, W. (2019). Monthly weather forecast and climate. Riyad, Saudi Arabia.

Baras, A., Bamhair, W., AlKhoshi, Y., Alodan, M., \& Engel-Cox, J. (2012). Opportunities and challenges of solar energy in Saudi Arabia. World Renewable Energy Forum, Denver.

Basahy, A. (1987). Suspended particulate and dustfall as pollutants in Riyadh city. Procceedings of Saudi Biological Society, 10, 261-269. 
Baseer, M. A., Meyer, J. P., Alam, M. M., \& Rehman, S. (2015). Wind speed and power characteristics for Jubail industrial city, Saudi Arabia. Renewable and Sustainable Energy Reviews, 52, 1193-1204. https://doi.org/10.1016/j.rser.2015.07.109

Bellini, E. (2019). Saudi Arabia plans new long-term RE targets, will resume tenders. PV magazine.

Blaisi, N. I. (2019). Construction and demolition waste management in Saudi Arabia: Current practice and roadmap for sustainable management. Journal of Cleaner Production, 221, 167-175. https://doi.org/10.1016/j.jclepro.2019.02.264

Caldera, U., Bogdanov, D., Afanasyeva, S., \& Breyer, C. (2018). Role of seawater desalination in the management of an integrated water and $100 \%$ renewable energy based power sector in Saudi Arabia. Water, 10(1), 3. https://doi.org/10.3390/w10010003

Chandrasekharam, D., Lashin, A., Al Arifi, N., Chandrasekhar, V., \& Al Bassam, A. (2015). Clean Development Mechanism through Geothermal, Saudi Arabia. Transport 446000(181000), 161000.

Demirbas, A., Hashem, A. A., \& Bakhsh, A. A. (2017). The cost analysis of electric power generation in Saudi Arabia. Energy Sources, Part B: Economics, Planning, and Policy, 12(6), 591-596. https://doi.org/10.1080/15567249.2016.1248874

Elani, U., \& Bagazi, S. (1998). The importance of silicon photovoltaic manufacturing in Saudi Arabia. Renewable energy, 14(1-4), 89-94. https://doi.org/10.1016/S0960-1481(98)00052-4

Faruqui, A., Hledik, R., Wikler, G., Ghosh, D., Prijyanonda, J., \& Dayal, N. (2011). Bringing demand-side management to the kingdom of Saudi Arabia. The Brattle Group.

Fiore, G., \& Selig, M. S. (2015). Simulation of damage for wind turbine blades due to airborne particles. Wind Engineering, 39(4), 399-418. https://doi.org/10.1260/0309-524X.39.4.399

Genna, A., Nehlig, P., Le Goff, E., Guerrot, C., \& Shanti, M. (2002). Proterozoic tectonism of the Arabian Shield. Precambrian Research, 117(1-2), 21-40. https://doi.org/10.1016/S0301-9268(02)00061-X

Goossens, D., \& Van Kerschaever, E. (1999). Aeolian dust deposition on photovoltaic solar cells: the effects of wind velocity and airborne dust concentration on cell performance. Solar Energy, 66(4), 277-289. https://doi.org/10.1016/S0038-092X(99)00028-6

Hottel, H. C. (1942). Performance of flat-plate solar heat collectors. Trans. ASME, 64, 91.

Hussein, M. T., Lashin, A., Al Bassam, A., Al Arifi, N., \& Al Zahrani, I. (2013). Geothermal power potential at the western coastal part of Saudi Arabia. Renewable and Sustainable Energy Reviews, 26, 668-684. https://doi.org/10.1016/j.rser.2013.05.073

Iamat. (2019). Saudi Arabia: Climate Information by City. Retrieved from https://www.iamat.org/country/saudi-arabia/climate-data

IEA, I. E. A. (2019). Explore energy data by category, indicator, country or region. Retrieved from https://www.iea.org/data-and-statistics? country=SAUDIARABI\&fuel=Energy\%20consumption\&indicator= Carbon\%20intensity\%20of\%20industry\%20energy\%20consumption.

Ike, C. (2013). The effect of temperature on the performance of a photovoltaic solar system in Eastern Nigeria. Research Inventy: International Journal Of Engineering And Science, 3(12), 10-14.

Kabbara, M. (2018). 4 factors drinving renewable energy in Saudi Arabia. Retrieved February 18, 2018, from https://www.weforum.org/agenda/2018/02/4-drivers-that-will-accelerate-renewable-energy-deployment-insaudi-arabia.

Kalogirou, S. A. (2005). Seawater desalination using renewable energy sources. Progress in energy and combustion science, 31(3), 242-281. https://doi.org/10.1016/j.pecs.2005.03.001

Kazem, H. A., \& Chaichan, M. T. (2015). Effect of humidity on photovoltaic performance based on experimental study. International Journal of Applied Engineering Research (IJAER), 10(23), 43572-43577.

Khalfallah, M. G., \& Koliub, A. M. (2007). Effect of dust on the performance of wind turbines. Desalination, 209(1-3), 209-220. https://doi.org/10.1016/j.desal.2007.04.030

Khan, M. S. M., \& Kaneesamkandi, Z. (2013). Biodegradable waste to biogas: renewable energy option for the Kingdom of Saudi Arabia. Int. J. Innov. Appl. Stud, 4(1), 101-113.

Knoema (2016). Saudi Arabia-CO2 emissions. 
Labban, A. (2015). Dust storms over Saudi Arabia: temporal and spatial characteristics, climatology and synoptic case studies.

Lashin, A., \& Al Arifi, N. (2014). "Geothermal energy potential of southwestern of Saudi Arabia" exploration and possible power generation": A case study at Al Khouba area-Jizan." Renewable and Sustainable Energy Reviews, 30, 771-789. https://doi.org/10.1016/j.rser.2013.10.037

Lashin, A., Al Arifi, N., Chandrasekharam, D., Al Bassam, A., Rehman, S., \& Pipan, M. (2015). Geothermal energy resources of Saudi Arabia: country update. Proceeding, World Geothermal Congress. https://doi.org/10.1016/j.jafrearsci.2015.05.016

McCarthy, N. (2016). The 20 Worst Cities Worldwide For Air Pollution. Statista.

Mosly, I., \& Makki, A. A. (2018). Current status and willingness to adopt renewable energy technologies in Saudi Arabia. Sustainability, 10(11), 4269. https://doi.org/10.3390/su10114269

Mundi, I. (2020). Saudi Arabia-GDP per capita.

Ng, B. J. H., Mao, Y., Chen, C.-L., Rajagopal, R., \& Wang, J.-Y. (2017). Municipal food waste management in Singapore: practices, challenges and recommendations. Journal of Material Cycles and Waste Management 19(1), 560-569. https://doi.org/10.1007/s10163-015-0405-8

Nizami, A., Rehan, M., Ouda, O. K., Shahzad, K., Sadef, Y., Iqbal, T., \& Ismail, I. M. (2015). An argument for developing waste-to-energy technologies in Saudi Arabia. Chemical Engineering Transactions, 45, 337-342.

Nizami, A., Shahzad, K., Rehan, M., Ouda, O., Khan, M., Ismail, I., ...Demirbas, A. (2017). Developing waste biorefinery in Makkah: A way forward to convert urban waste into renewable energy. Applied Energy, 186, 189-196. https://doi.org/10.1016/j.apenergy.2016.04.116

Obaid, R. R. (2015). Seasonal-Water Dams: A Great Potential for Hydropower Generation in Saudi Arabia. Int. J. of Sustainable Water and Environmental Systems, 7(1), 1-7.

Office-REPDO, R. E. P. D. (2019). The National Renewable Energy Program. Retrieved from https://www.powersaudiarabia.com.sa/web/index.html

Omubo-Pepple, V., Israel-Cookey, C., \& Alaminokuma, G. (2009). Effects of temperature, solar flux and relative humidity on the efficient conversion of solar energy to electricity. European Journal of Scientific Research, 35(2), 173-180.

Ouda, O., Raza, S., Nizami, A., Rehan, M., Al-Waked, R., \& Korres, N. (2016). Waste to energy potential: a case study of Saudi Arabia. Renewable and Sustainable Energy Reviews, 61, 328-340. https://doi.org/10.1016/j.rser.2016.04.005

Ouda, O. K., Cekirge, H. M., \& Raza, S. A. (2013). An assessment of the potential contribution from waste-to-energy facilities to electricity demand in Saudi Arabia. Energy Conversion and Management, 75, 402-406. https://doi.org/10.1016/j.enconman.2013.06.056

Özkazanç-Pan, B. (2019). Transnational Migration and New Subjects of Work. Bristol University Press.

Panjwani, M. K., \& Narejo, G. B. (2014). Effect of humidity on the efficiency of solar cell (photovoltaic). International Journal of Engineering Research and General Science, 2(4), 499-503.

Patlitzianas, K. D., Doukas, H., \& Psarras, J. (2006). Enhancing renewable energy in the Arab States of the Gulf: Constraints \& efforts. Energy policy, 34(18), 3719-3726. https://doi.org/10.1016/j.enpol.2005.08.018

Power, A. (2018). Saudi Arabia Is Unlocking the Potential of Wind Energy.

Ramli, M. A., Hiendro, A., \& Al-Turki, Y. A. (2016). Techno-economic energy analysis of wind/solar hybrid system: Case study for western coastal area of Saudi Arabia. Renewable energy, 91, 374-385. https://doi.org/10.1016/j.renene.2016.01.071

Ratikainen, K. W. (2017). Transitioning to renewable energy in Saudi Arabia-A multi-level perspective analysis of the Saudi renewable energy policies.

Rehan, M., Gardy, J., Demirbas, A., Rashid, U., Budzianowski, W., Pant, D., \& Nizami, A. (2018). Waste to biodiesel: A preliminary assessment for Saudi Arabia. Bioresource technology, 250, 17-25. https://doi.org/10.1016/j.biortech.2017.11.024 
Rehman, S., \& Ahmad, A. (2004). Assessment of wind energy potential for coastal locations of the Kingdom of Saudi Arabia. Energy, 29(8), 1105-1115. https://doi.org/10.1016/j.energy.2004.02.026

Rehman, S., Bader, M. A., \& Al-Moallem, S. A. (2007). Cost of solar energy generated using PV panels. Renewable and sustainable energy reviews, 11(8), 1843-1857. https://doi.org/10.1016/j.rser.2006.03.005

Reinecke, A. J., van Wyk, M., \& Reinecke, S. A. (2016). The influence of soil characteristics on the toxicity of oil refinery waste for the springtail Folsomiacandida (Collembola). Bulletin of environmental contamination and toxicology, 96(6), 804-809. https://doi.org/10.1007/s00128-016-1792-9

SEEC, S. E. E. C. (2020). Energy Sector. Retrieved from https://www.seec.gov.sa/en/blog/industrial

Shamachurn, H., \& Betts, T. (2016). Experimental Study of the Degradation of Silicon Photovoltaic Devices under Ultraviolet Radiation Exposure. Journal of Solar Energy. https://doi.org/10.1155/2016/2473245

Sulaiman, S. A., Hussain, H. H., Leh, N., \& Razali, M. S. (2011). Effects of Dust on the Performance of PV Panels. World Academy of Science, Engineering and Technology, 58, 588-593.

Tlili, I. (2015). Renewable energy in Saudi Arabia: current status and future potentials. Environment, development and sustainability, 17(4), 859-886. https://doi.org/10.1007/s10668-014-9579-9

Tolba, M. K., \& Saab, N. (2008). Arab environment: future challenges. Arab Forum for Environment and Development Beyrouth.

Wakim, F. (1981). Introduction of PV power generation to Kuwait. Kuwait Institute for Scientific Researchers, Kuwait City.

Zell, E., Gasim, S., Wilcox, S., Katamoura, S., Stoffel, T., Shibli, H., ...Al Subie, M. (2015). Assessment of solar radiation resources in Saudi Arabia. Solar Energy, 119, 422-438. https://doi.org/10.1016/j.solener.2015.06.031

\section{Copyrights}

Copyright for this article is retained by the author(s), with first publication rights granted to the journal.

This is an open-access article distributed under the terms and conditions of the Creative Commons Attribution license (http://creativecommons.org/licenses/by/4.0/). 